\title{
Broadening Language Learning Strategies for Asian EFL Students
}

\author{
Douglas Meyer \\ Victoria University of Wellington, New Zealand
}

\begin{abstract}
This discussion paper looks into the field of language learning strategies (LLS) and makes a comparison to the traditional EFL context of many Asian learners. It is argued here that there is a noticeable gap between Western LLS and the manner in which most Asian students are educated, suggesting a need for either a new culturally sensitive list of strategies or a broadening of existing strategies. The author first identifies some of the definitions of LLS by early researchers, and then discusses common traditional Asian learning and teaching styles. A number of strategies to be explicitly taught are suggested as a means of enhancing learner study habits and second language acquisition (SLA).
\end{abstract}

The topic of language learning strategies (LLS) developed along with the field of cognitive psychology (Williams \& Burden, 1997). Definitions of LLS include "routines used to facilitate learning and retrieving information" (Wenden \& Rubin, 1987, p. 19), "intentional behavior to learn or remember new information" (Richards, Platt, \& Platt, 1992, p. 209), and "attempts to develop linguistic and sociolinguistic competence in a target language" (Faerch \& Kasper, 1983, p. 67).

A distinction must be drawn between LLS and learning styles. Individual learning styles are influenced by personality (e.g., self-esteem, anxiety) and cognition - left brain / right brain orientation and / or ambiguity tolerance (Brown, 2007). Styles are "an individual's natural, habitual, and preferred ways of absorbing, processing, and retaining new information and skills" (Kinsella, 1995, p. 171). Successful language learners know themselves well and are flexible with regard to their own styles and the myriad of LLS.

What are some specific things learners can do to enhance their second language acquisition $(\mathrm{SLA})$ ? It has been argued by early LLS researchers that good language learners have been known to engage in some of the following activities: 
- Taking responsibility for their own learning

- Creatively experimenting with new words and grammar

- Making opportunities for L2 (second language use) outside of the classroom

- Focusing on gist rather than the details of $L 2$

- Using memory strategies (e.g., mnemonics) to aid recalling new words

- Using contextual clues to aid comprehension

- Learning to make intelligent guesses and using strategies to keep a conversation going

(Rubin \& Thompson, 1982)

This paper will look at ways that existing Asian LLS can be broadened to foster longer-term productive skills-based outcomes rather than short-term high-stakes testing outcomes.

\section{The Asian Context: Challenges for EFL Learners}

The educational environment. There are approximately 2 billion people in Asia, where perceived opportunities for socio-economic advantages (Kirkpatrick, 2010) have fueled the growing EFL market. For most young learners, preparing for high-stakes testing (e.g., entrance exams) is a priority above all else. For several decades, the traditional grammar-translation teaching method has ruled classrooms in teacher-centered, book-oriented lessons intended to help students pass major exams. In addition, small fortunes are spent (in wealthier countries) on private education in cram schools (Moon, 2006; Weisman, 1992), feeding the never-ending competition for entry into good schools and brand-name corporations.

Several early western researchers (below) have noted the tendency for many Asian learners to neither ask questions nor disagree with their teacher in class. From their point of view, Asian learners are more likely than western learners to exhibit some of the following characteristics:

- Quiet, shy, and reticent

- Avoidance of uncertainty and risk-taking

- Reliance on teachers for knowledge (i.e., independent learning is limited)

- Reliance on memorization, planning, and carefully following guidelines

- Preference to listen (rather than speak) to the teacher

- Rarely raise their hands to answer the teacher's questions

(Harshbarger, Ross, Tafoya, \& Via, 1986; Liu \& Littlewood, 1997; Oxford \& Burry-Stock, 1995)

Asian students are also often under heavy pressure to succeed from parents and teachers (Kim, 2007; Rampell, 2011). Most Asian students must take entrance exams for admission into leading high schools and universities. A modern day rite of passage, the intense pressure to study and succeed amid intense competition is widely known as exam hell. In this kind of high-pressure educational environment, a considerable toll can be taken on mental and physical health (Lee \& Larson, 2000). Under such stress to perform well, learners are unlikely to adapt risky, unknown LLS, and may rather study in traditional ways. Indeed, one researcher argues that in the case of Chinese learners, unfamiliar (i.e., western) teaching methodologies are the reason behind reticence, passivity, and risk-avoidance in class (Cheng, 2000).

Others have argued that many of these studies of LLS were done in English-speaking countries or looked at how Westerners learn foreign languages abroad (Rao, 2001). Others have criticized the East-West dichotomy and the unfair labels it generates for Asian learners (Kubota, 1999). Nonetheless, traditional LLS match the medium and short-term goals of passing high- 
stakes exams and have thus served Asian students well. Students have been admitted to good universities and jobs have been secured.

However, the global marketplace is demanding more productive language skills, communicability, and competence in English. In Asia, which accounts for an increasingly larger share of global economic output, companies are looking for recruits who possess foreign language abilities (Gross, 1996) that are usually not taught in schools. Encouraging the addition of communication-oriented LLS might boost upward mobility in the early years following graduation.

The physical environment. As shown in Table 1, only a handful of former colonial nations in Asia maintain English as an official language. In vast areas of East and Southeast Asia, English remains a foreign language with very small and spread out English target language communities, making it very difficult for L2 learners to find meaningful opportunities to use the language with native speakers (NS). In nations such as South Korea and Japan, ethnic homogeneity approaches approximately $98 \%$ (The World Factbook, n.d.).

Of course, in the past few decades, the number of non-native speakers (NNS) has skyrocketed, far outnumbering NS (Crystal, 2003). Increasingly, discourse will be between NNS using English as a lingua franca. The idea of integrativeness (Gardner, 1982) is indeed giving way from NS target language communities to global language NNS communities. With this in mind, LLS that build on communicative competence will become increasingly important.

\section{Table 1}

\section{Asian Countries Using English as an Official Language}

\begin{tabular}{|l|l|}
\hline Country & Official Languages \\
\hline Hong Kong & English and Chinese \\
\hline India & English and Hindi \\
\hline Pakistan & English and Urdu \\
\hline The Philippines & English and Filipino \\
\hline Singapore & English, Chinese, Malay, and Tamil \\
\hline
\end{tabular}

Note. Lukóczky \& Guszlev, 1997.

\section{Challenges in the Asian Context}

For many learners, English is primarily a means of upward mobility (Ross, 2008) and a highstakes testing subject in their own society. Some researchers (Holliday, 2003; Kubota, 1999; Rao, 2001; Watkins, 2000) have criticized the common Western approaches to LLS and argued in favor of a more culturally appropriate approach that recognizes both learner constraints and instrumental goals. For example, in test-centered learning environments, success is often defined as passing important entrance exams rather than as actually being able to use a language. Secondary school teachers spend a lot of time and effort preparing students for these exams, rendering the Western communication-oriented LLS of lesser importance.

Moreover, existing LLS are aimed at doing well on high-stakes exams (e.g., IELTS, TOEIC, TOEFL) and rarely require the need for $\mathrm{L} 2$ speaking skills (excluding the IELTS interview and TOEFL iBT speaking tasks). The assessment of speaking skills largely remains a costly, impractical element for many language exams. As a result, teachers and learners naturally 
focus on the elements tested: grammar, vocabulary, listening, reading, summarizing passages, and, for entrance exams, grammar-translation items.

This paradigm contrasts with the list of LLS drawn up by Western researchers (Table 2) who have examined cases of foreign students in an English-speaking environment. It is possible at this point to argue that LLS are connected to desired outcomes, of which two have emerged dominant: the testing orientation and the communicability orientation. Given that spoken English is increasingly in demand in the global marketplace (e.g., university admissions, upwardly mobile employment opportunities), this paper will focus on broadening the scope of LLS used in Asia to supplement existing test-oriented strategies with those that suit communicability goals and objectives.

Table 2

Contrasting Traditional Western and Asian Language Learning Strategies

\begin{tabular}{|c|c|}
\hline $\begin{array}{l}\text { Traditional Western LLS } \\
\text { (Rubin \& Thompson, 1982) }\end{array}$ & $\begin{array}{l}\text { Traditional Asian LLS } \\
\text { (Liu \& Littlewood,1997) }\end{array}$ \\
\hline $\begin{array}{l}\text { Students take charge of / responsibility for } \\
\text { their own language learning. }\end{array}$ & $\begin{array}{l}\text { Students often rely on teachers to deliver } \\
\text { detailed guidelines in very structured lessons; } \\
\text { autonomy is generally not supported. }\end{array}$ \\
\hline $\begin{array}{l}\text { Students creatively develop a fee/for L2 by } \\
\text { experimenting with words and grammar. }\end{array}$ & $\begin{array}{l}\text { Students use the grammar-translation method } \\
\text { and are likely to use memorization strategies. }\end{array}$ \\
\hline $\begin{array}{l}\text { Students use contextual clues to aid in } \\
\text { comprehension. }\end{array}$ & $\begin{array}{l}\text { Students tend to focus on individual word } \\
\text { meanings and grammar points removed from } \\
\text { context. }\end{array}$ \\
\hline Students learn to make intelligent guesses. & $\begin{array}{l}\text { Students tend to avoid risk-taking and a } \\
\text { possible loss of face caused by mistakes. }\end{array}$ \\
\hline $\begin{array}{l}\text { Students create opportunities for L2 practice } \\
\text { outside of the classroom. }\end{array}$ & $\begin{array}{l}\text { Students rarely have authentic opportunities } \\
\text { for } L 2 \text { use; some may be reluctant to engage } \\
\text { a native speaker. }\end{array}$ \\
\hline $\begin{array}{l}\text { Students do not get flustered and continue to } \\
\text { talk or listen without understanding every } \\
\text { word. }\end{array}$ & $\begin{array}{l}\text { Students have very limited experience } \\
\text { engaging in extended discourse; students } \\
\text { dislike uncertainty and a lack of structure. }\end{array}$ \\
\hline
\end{tabular}

\section{Broadening LLS Principles: Goals and Outcomes}

If teacher is inclined to broaden learner strategies, certain gradual, specific steps must be made to introduce these strategies in the language classroom. For students who tend to rely excessively on the teacher, some independence should be granted in the form of an autonomous framework. Give students a list of assignments to choose from, allowing them to pursue topics of interest in the target language. The freedom and control over their own language learning process may, if supported by the teacher, improve students' intrinsic motivation due to the satisfactory experience of achieving knowledge on their own. Moreover, group work goes hand in hand with autonomy and individual responsibility. For example, small groups can divide language tasks (outlined by the teacher) as homework. In the following class, each group member presents his or her work. Individual members are unlikely to fail in their responsibility to the group and will be pressured to take charge of their own learning. This should work well in societies where group work is common; however, the teacher must 
package the concept as individual responsibility to the language team, where each member has an autonomous role to play.

Developing a feel for the language also involves the teacher. Wherever possible, language play can be encouraged, especially following a grammar lesson. Allow students to play with the patterns taught, exercising freedom and creativity within the guidelines of lesson objectives. Let learners write experiment with writing funny English sentences of their own making by using characters from local anime or lore, rather than stale grammar book patterns. Instead of "Mr. Smith went to the store to buy milk," enthusiastic students might practice writing, "Godzilla went to the game center to eat sushi." This will reinforce the grammatical pattern while fostering creativity, motivation, and autonomy, and hopefully push the boundaries of their abilities.

Using contextual clues to aid comprehension can also be encouraged by removing the abstract element from grammar lessons. For example, when focusing on form, let students create a class character that will be the subject in sample sentences. Replace him, her, Student A, etc., with a concrete character that will connect the grammar patterns in meaningful ways, quite possibly following a story that appeals to learners while still following lesson objectives.

In regard to risk avoidance, creating a positive classroom atmosphere will make learners more willing to take risks and tackle ambiguity in an L2. Teachers could share some personal stories about embarrassing L2 mistakes made while abroad, thereby building deeper relations with students and demonstrating that mistakes are nothing to dwell upon; rather, they are merely unplanned learning opportunities. Moreover, the teacher can help reduce foreign language anxiety by drawing attention to what students are doing right, rather than wrong.

Creating opportunities for meaningful L2 use outside of class can be addressed in this digital age, with computers and Internet access making headway into even the most remote villages of Asia. Cyberspace is an inexhaustible source of opportunities for English use. By using sites such as Facebook, Twitter, English Central, YouTube, or Skype, learners have countless chances to interact with other Asian students learning English. This could motivate students by showing that they are not alone in their struggles to learn English.

The final point is perhaps the most daunting. How can young students (many of whom have no experience talking to a native speaker) be trained to not become flustered when faced with extensive listening of unplanned speech? Like many teaching points, the answer is to drill and practice. Allow class time for pairs of students to practice such speech on familiar topics with little preparation, forcing output and extensive listening. Follow up with a brief question and answer session, also in pairs. Teachers can also provide opportunities for extensive listening by sharing three-minute personal stories about their own struggles learning English.

Other activities should be kept simple and not involve a heavy cognitive load, e.g., a telephone numbers quiz. Students can pair up and take turns reciting a list of eight telephone numbers. While one partner reads, the other listens and writes. After checking for accuracy, students can compete against each other (or themselves) by trying to read the numbers as quickly as possible. Another example is dictogloss; students work together to reconstruct a short text read by the teacher. Of course, the topic is discussed beforehand, and the students are able to take notes when listening to the reading a second time. 


\section{Explicit Teaching of LLS: Strategies-Based Instruction}

Often, Asian EFL teachers are caught up in the instruction of language form and lose sight of empowering students to acquire knowledge on their own. This complex step requires both teachers and learners to be fully aware of their strengths and weaknesses, styles, and preferences as individual learners. This may be a challenging but necessary step to raise awareness in language learning, for only then can learners adopt strategies for success and compensate for individual weaknesses in SLA. To motivate students to examine their own weaknesses, it should be pointed out doing so will help them to become more effective learners who may be able to boost test scores as a result.

The second step is for teachers to make their students aware of the various LLS available and make explicit attempts to introduce LLS in class. This can be done through informal class discussions, readings, lectures, and questionnaires. Strategies for Success: A Practical Guide to Learning English (Brown, 2002) is an affordable, easy-to-use workbook full of questionnaires designed to help students discover their learning styles and learn strategies (see Table 3 below) to compensate for weaknesses in SLA. Such activities may take some time in class, but these self-discoveries may reward students long after the course has been completed.

The final step involves the active, conscientious application of LLS to classroom instruction and evaluation. With regard to the latter, alternative means of assessment by the teacher would aid in forcing students to acquire and practice new learning skills. Ideally, course evaluation could include pair / group work presentation projects, open-ended free response type questions, portfolio work, and autonomous writing assignments.

In encouraging students to become better language learners, teachers must encourage new social constructs and classroom behavior. Teachers wishing to foster a more communicative approach must first actively work on creating a positive atmosphere for teamwork and learning, reducing foreign language anxiety, and boosting student self-confidence and autonomy. Such a bold initiative could even be posted in class as a constant reminder to students (and the teacher) about what qualities will help with L2 acquisition.

\section{Table 3}

Ten Commandments for Good Language Learning (Brown, 2007, p. 268)

\begin{tabular}{|l|l|}
\hline Teacher's Version & Learner's Version \\
Lower inhibitions & Fear not! \\
Encourage risk-taking & Dive in \\
Build self-confidence & Believe in yourself \\
Develop intrinsic motivation & Seize the day \\
Engage in cooperative learning & Love thy neighbor \\
Use right-brain processes & Get the BIG picture \\
Promote ambiguity tolerance & Cope with the chaos \\
Practice intuition & Go with your hunches \\
Process error feedback & Make mistakes work FOR you \\
Set personal goals & Set your own goals \\
\hline
\end{tabular}

A key component of strategies-based instruction will be the transition from testing-oriented LLS to strategies that promote the L2 as a spoken language. It may be difficult for teachers to make any radical changes; modifying and broadening existing LLS might make the transition smoother. For example, shy students can be put into pairs or small groups for discussions on 
their choice of topics from a list provided by the teacher. Colloquial phrases (not found in exams) can be memorized as a part of promoting L2 as a living, dynamic language. Students can be rewarded for asking questions from a teacher who deliberately leaves out critical information to elicit questions. Opportunities for language use outside the class can be created in the form of English clubs, parties, or other social events in the area.

\section{Conclusion}

This paper looked at some of the common definitions of LLS, as described by early researchers in the field, and compared them with common strategies used in Asia. The strategies used are reflected in the goals and objectives of the learners. In test-centered learning environments, the traditional methods are tried and true.

However, the global marketplace is increasingly calling for recruits who can use language effectively as a skill rather than an academic subject. A number of strategies were suggested for the introduction and implementation of communicative LLS in language classrooms. LLS should be introduced gradually and persistently, since it is possible that some of these new ideas will initially be met with confusion and resistance.

By broadening existing LLS to include longer-term goals of communicability, Asian learners will be well situated to become leaders in the global marketplace as non-native speakers of English. However, it is up to teachers to look beyond high-stakes testing towards the biggest test of all: success in the modern international workplace.

\section{Author Note}

Douglas Meyer, School of Linguistics and Applied Language Studies, Victoria University of Wellington, New Zealand.

Correspondence concerning this article should be addressed to Douglas Meyer, Victoria University of Wellington (LALS), P.O. Box 600, Wellington, New Zealand 6140. E-mail: douglas.meyer@vuw.ac.nz 


\section{References}

Brown, H. D. (2002). Strategies for success: A practical guide to learning English. New York, NY: Pearson Education.

Brown, H. D. (2007). Teaching by principles: An interactive approach to language pedagogy (3rd ed.). New York, NY: Pearson Education.

Cheng, X. (2000). Asian students' reticence revisited. System, 28, 435-446. http://dx.doi.org/10.1016/S0346-251X(00)00015-4

Crystal, D. (2003). English as a global language (2nd ed.). Cambridge, England: Cambridge University Press.

Faerch, C., \& Kasper, G. (1983). Communication strategies in interlanguage communication. London, England: Longman.

Gardner, R. C. (1982). Language attitudes and language learning. In E. Bouchard Ryan \& H. Giles (Eds.), Attitudes towards language variation (pp. 132-147). London, England: Edward Arnold.

Gross, A. (1996). Recruiting in Asia. Benefits \& Compensation International, 26(5), 14-18. Retrieved from http://www.pacificbridge.com/publications/recruiting-in-asia/

Harshbarger, B., Ross, T., Tafoya, S., \& Via, J. (1986). Dealing with multiple learning styles in the ESL classroom. Symposium presented at the Annual TESOL Meeting, San Francisco, CA.

Holliday, A. (2003). Social autonomy: Addressing the dangers of culturism in TESOL. In D. Palfreyman \& R. C. Smith (Eds.), Learner autonomy across cultures: Language education perspectives (pp. 110-128). London, England: Palgrave Macmillan.

Kim, H. S. (2007, October 10). Parents push too much for education. The Korea Times. Retrieved from https://www.koreatimes.co.kr/www/news/special/2012/02/\%20181_11640.html

Kinsella, K. (1995). Understanding and empowering diverse learners in the ESL classroom. In J. Reid (Ed.), Learning styles in the ESL/EFL classroom (pp. 170-195). Boston, MA: Heinle \& Heinle.

Kirkpatrick, A. (2010). English as a lingua franca in ASEAN: A multilingual model. Hong Kong University Press.

Kubota, R. (1999). Japanese culture constructed by discourses: Implications for applied linguistics research and ELT. TESOL Quarterly, 33(1), 9-35. http://dx.doi.org/10.2307/3588189

Lee, M., \& Larson, R. (2000). The Korean 'examination hell': Long hours of studying, distress, and depression. Journal of Youth and Adolescence, 29(2), 249-271. http://dx.doi.org/10.1023/A:1005160717081

Liu, N. F., \& Littlewood, W. (1997). Why do many students appear reluctant to participate in classroom learning discourse? System, 25(3), 371-384. http://dx.doi.org/10.1016/S0346251X(97)00029-8

Lukóczky, O., \& Guszlev, A. (1997). English language - around the world! [Demographic map]. Retrieved from http://lazarus.elte.hu/ guszlev/gb/english.htm

Moon, I. (2006, December 11). Where a teacher can make millions. Bloomberg Businessweek. Retrieved from http://www.businessweek.com/magazine/content/06_50/b4013056.htm

Oxford, R. L. \& Burry-Stock, J. A. (1995). Assessing the use of language learning strategies worldwide with the ESL/EFL version of the Strategy Inventory for Language Learning (SILL). System, 23(1), 1-23. http://dx.doi.org/10.1016/0346-251X(94)00047-A

Rampell, C. (2011, September 1). Do parents put too much pressure on students? The New York Times. Retrieved from http://economix.blogs.nytimes.com/2011/09/01/do-parents-puttoo-much-pressure-on-students/ 
Rao, Z. (2001). Matching teaching styles with learning styles in East Asian contexts. The Internet TESL Journal, 77). Retrieved from http://iteslj.org/Techniques/ZhenhuiTeachingStyles.html

Ross, S. J. (2008). Language testing in Asia: Evolution, innovation, and policy changes. Language Testing, 25(1), 5-13. http://dx.doi.org/10.1177/0265532207083741

Richards, J. C., Platt, J. T., \& Platt, H. K. (1992). Longman dictionary of language teaching and applied linguistics. Essex, England: Longman.

Rubin, J., \& Thompson, I. (1982). How to be a more successful language learner. Boston, MA: Heinle \& Heinle.

Watkins, D. (2000). Learning and teaching: A cross-cultural perspective. School of Leadership and Management, 20(2), 161-173. http://dx.doi.org/10.1080/13632430050011407

Wenden, A. L., \& Rubin, J. (1987). Learner strategies in language learning. Englewood Cliffs, NJ: Prentice Hall.

Weisman, S. R. (1992, April 27). How do Japanese students do it? They cram. The New York Times. Retrieved from http://www.nytimes.com/1992/04/27/world/how-do-japan-sstudents-do-it-they-cram.html?pagewanted=all\&src=pm

Williams, M., \& Burden, R. L. (1997). Psychology for language teachers: A social constructivist approach. Cambridge, England: Cambridge University Press.

The World Factbook (n.d.). Retrieved January 4, 2012 from the U.S. Central Intelligence Agency website: https://www.cia.gov/library/publications/the-world-factbook/index.html 